\title{
A 2500 year record of natural and anthropogenic soil erosion in South Greenland
}

\author{
Charly Massa ${ }^{\mathrm{a}, *}$, Vincent Bichet ${ }^{\mathrm{a}}$, Émilie Gauthier ${ }^{\mathrm{a}}$, Bianca B. Perren ${ }^{\mathrm{a}}$, Olivier Mathieu ${ }^{\mathrm{b}}$, \\ Christophe Petit $^{c}$, Fabrice Monna ${ }^{\mathrm{d}}$, Jacques Giraudeau ${ }^{\mathrm{e}}$, Rémi Losno ${ }^{\mathrm{f}}$, Hervé Richard ${ }^{\mathrm{a}}$ \\ ${ }^{a}$ UMR CNRS 6249, Laboratoire Chrono-environnement, Université de Franche-Comté, 16 route de Gray, 25030 Besançon Cedex, France \\ ${ }^{\mathrm{b}}$ UMR CNRS 5561, Biogéosciences, Université de Bourgogne, 6 bd Gabriel, 21000 Dijon, France \\ ${ }^{c}$ UMR CNRS 7041, ArScAn, Archéologies et Sciences de l'Antiquité, Université de Paris 1, 3 rue Michelet, 75006 Paris, France \\ d UMR CNRS 5594, ARTéHIS, Université de Bourgogne, 6 bd Gabriel, 21000 Dijon, France \\ ${ }^{\mathrm{e}}$ UMR CNRS 5805, EPOC, Université de Bordeaux 1, Avenue des Facultés, 33405 Talence Cedex, France \\ ${ }^{\mathrm{f}}$ UMR CNRS 7583, LISA, Université Paris-Diderot, 61 av. du Gal de Gaulle, 94010 Créteil Cedex, France
}

\section{A R T I C L E I N F O}

\section{Article history:}

Received 15 July 2011

Received in revised form

9 November 2011

Accepted 15 November 2011

Available online $\mathrm{xxx}$

\section{Keywords:}

Greenland

Norse

Eastern settlement

Landnám

Agriculture

Soil erosion

\begin{abstract}
A B S T R A C T
The environmental impact of the Norse landnám (colonization) in Greenland has been studied extensively. But to date, no study has quantified the soil erosion that Norse agricultural practices are believed to have caused. To resolve this problem, a high resolution sedimentary record from Lake Igaliku in South Greenland is used to quantitatively reconstruct 2500 years of soil erosion driven by climate and historical land use. An accurate chronology, established on $18 \mathrm{AMS}{ }^{14} \mathrm{C}$, and ${ }^{210} \mathrm{~Pb}$ and ${ }^{137} \mathrm{Cs}$ dates, allows for the estimation of detritic fluxes and their uncertainties. Land clearance and the introduction of grazing livestock by the Norse around $1010 \mathrm{AD}$ caused an acceleration of soil erosion up to $\sim 8 \mathrm{~mm}$ century $^{-1}$ in 1180 AD which is two-fold higher than the natural pre-landnám background. From 1335 AD to the end of the Norse Eastern Settlement (in the mid-fifteenth century), the vegetation began to recover from initial disturbance and soil erosion decreased. After an initial phase of modern sheep breeding similar to the medieval one, the mechanization of agriculture in the 1980s caused an unprecedented soil erosion rate of up to $\sim 21 \mathrm{~mm}^{\text {century }}{ }^{-1}$, five times the pre-anthropogenic levels. Independently, a suite of biological and geochemical proxies (including Ti and diatom concentrations, C:N ratio, $\delta^{13} \mathrm{C}$ and $\delta^{15} \mathrm{~N}$ of organic matter) confirm that the medieval and modern anthropogenic erosion far exceeds any natural erosion over the last 2500 years. Our findings question the veracity of the catastrophic scenario of overgrazing and land degradation considered to have been the major factor responsible for Norse settlement demise. They also shed light on the sustainability of modern practices and their consequences for the future of agriculture in Greenland.
\end{abstract}

(C)

\section{Introduction}

Understanding the interactions between climate and human impact on lake sediments has become an important issue of paleolimnology (Dearing et al., 2008; Battarbee and Bennion, 2010). In this framework, the westward migration of the Scandinavian settlers (Norse) across the North Atlantic region during the 8th-10th centuries is an ideal case study for understanding the interactions between human societies and their environment. The absence of established agricultural systems in Greenland before the Norse colonization (landnám), well documented by the archaeological and medieval literature, namely "the Sagas" (for a in-depth review see Dugmore et al., 2005 and references therein), provides

\footnotetext{
* Corresponding author.

E-mail address: charly.massa@edu.univ-fcomte.fr (C. Massa).
}

a unique opportunity to study the human impacts through a rapid colonization of a pristine landscape (e.g. Fredskild, 1973; Gauthier et al., 2010; Schofield and Edwards, 2011). The history of the Greenland settlements (the "Eastern Settlement" in the far south and the "Western Settlement" in modern Nuuk district further north), from the end of the 10th century to the late 15th century, is also an iconic example of the impact of changing climate on human population (McGovern, 1991; Barlow et al., 1997; Dugmore et al., 2007). The chronology of the abandonment is unclear as are its causes. The only consensus is the role of the deteriorating climatic conditions of the 'Little Ice Age' which likely isolated the community and reduced agricultural yields (eg. Dansgaard et al., 1975; Stuiver et al., 1995; Barlow et al., 1997; Patterson et al., 2010).

Among the many reasons proposed to explain the disappearance of the Norse from Greenland, overgrazing and excessive soil erosion may have lead to a dramatic decrease of grassland and fodder production crucial to Norse animal husbandry (eg. Gad, 1970; 
Jacobsen and Jakobsen, 1986; Jacobsen, 1987; Fredskild, 1988; Hansen, 1991; Jakobsen, 1991; Fredskild, 1992; Mainland, 2006). Apart from one exception (Rutherford, 1995), increased soil erosion is documented from all investigations of Norse farming impacts. Severe soil erosion was also observed in a few areas of South Greenland during the 1970s and Fredskild (1988) suggested that the Norse settlers could be responsible for its initiation. Concerned about a possible adverse environmental impact comparable to that postulated for the Norse, the Danish authorities conducted an extensive study of the impacts of sheep grazing on vegetation and soils (Hansen, 1991; Sandgren and Fredskild, 1991; Fredskild, 1992). Afterwards it turned out that the only substantial eroded area (ca. $10 \mathrm{~km}^{2}$ ) is situated near Igaliku Kujalleq (Sondre Igaliku, Fig. 1a). Moreover, some authors argued that the extensive sand horizons observed in lakes and soil profiles of this area could be the result of aeolian inputs as well as sediment influx from erosion and transportation in the immediate catchments (Mikkelsen et al., 2001; Andresen et al., 2004; Lassen et al., 2004; Kuijpers and Mikkelsen, 2009).

To assess the problem of soil erosion in Greenland, it must be directly estimated through the calculation of sediment yield, before, during and after the medieval occupation. Lake reservoirs have been widely used in to quantify erosion rates and to determine changes in sediment yield due to agriculture (e.g. Dearing, 1992; Chiverrell, 2006; Enters et al., 2008; Boyle et al., 2011). To date there is no reliable quantification of erosion in the Greenland settlements that could support the mass erosion hypothesis. Fredskild's pioneering work showed strong evidence of soil erosion (Sandgren and Fredskild, 1991; Fredskild, 1992) but poor chronological control does not allow the sediment yield to be estimated. Recent efforts on peat deposits (Edwards et al., 2008; Schofield and Edwards, 2011), soil sections (Buckland et al., 2009) and archaeological trenches (Schofield et al., 2008) have produced high-resolution records of the impact of Norse farming, with reliable chronology through AMS dating of terrestrial plant macrofossils. However, systematic sedimentological hiatuses due to peat cutting or low sediment accumulation rates do not adequately place the records in a late-Holocene palaeoclimatic context. In light of the previous studies mentioned above, nothing definitive can be said as to whether the Norse agricultural practices caused widespread land degradation.

Here, we present a quantified reconstruction of past soil erosion based on the analysis of a well dated lacustrine sediment record from Igaliku, near the major archaeological site of Garðar, in South Greenland. The objective of the present study is to estimate soil erosion within the catchment area of Lake Igaliku using the detritic and organic inputs into the lake. The reliability of our estimate is controlled by a set of geochemical and ecological parameters including, titanium content, bulk organic matter geochemistry and diatom valve concentration. As sheep farming was reintroduced at a large scale in the area during the 1920s, we have also compared medieval and recent soil erosion to place the Norse impacts in a modern context. Both erosion rates and sedimentological proxies were interpreted in the context of past arctic climate and historical land-use. This work builds on paleoecological data obtained from the same core (Perren et al., in press; Gauthier et al., 2010) and constitutes a comprehensive reconstruction of human impact on an area of prime importance during the Norse period.

\section{Study area}

\subsection{The Igaliku lake system}

Lake Igaliku (unofficial name, $61^{\circ} 00^{\prime} \mathrm{N}-45^{\circ} 26^{\prime} \mathrm{W}, 15 \mathrm{~m}$ asl) is located in a low valley between the head of Igalikup Kangerlua (Igaliku fjord) and Tunulliarfik fjord (Erik's fjord) (Fig. 1a,b). It is a north-south oriented lake with a surface area of 34.6 ha (Fig. 1c).

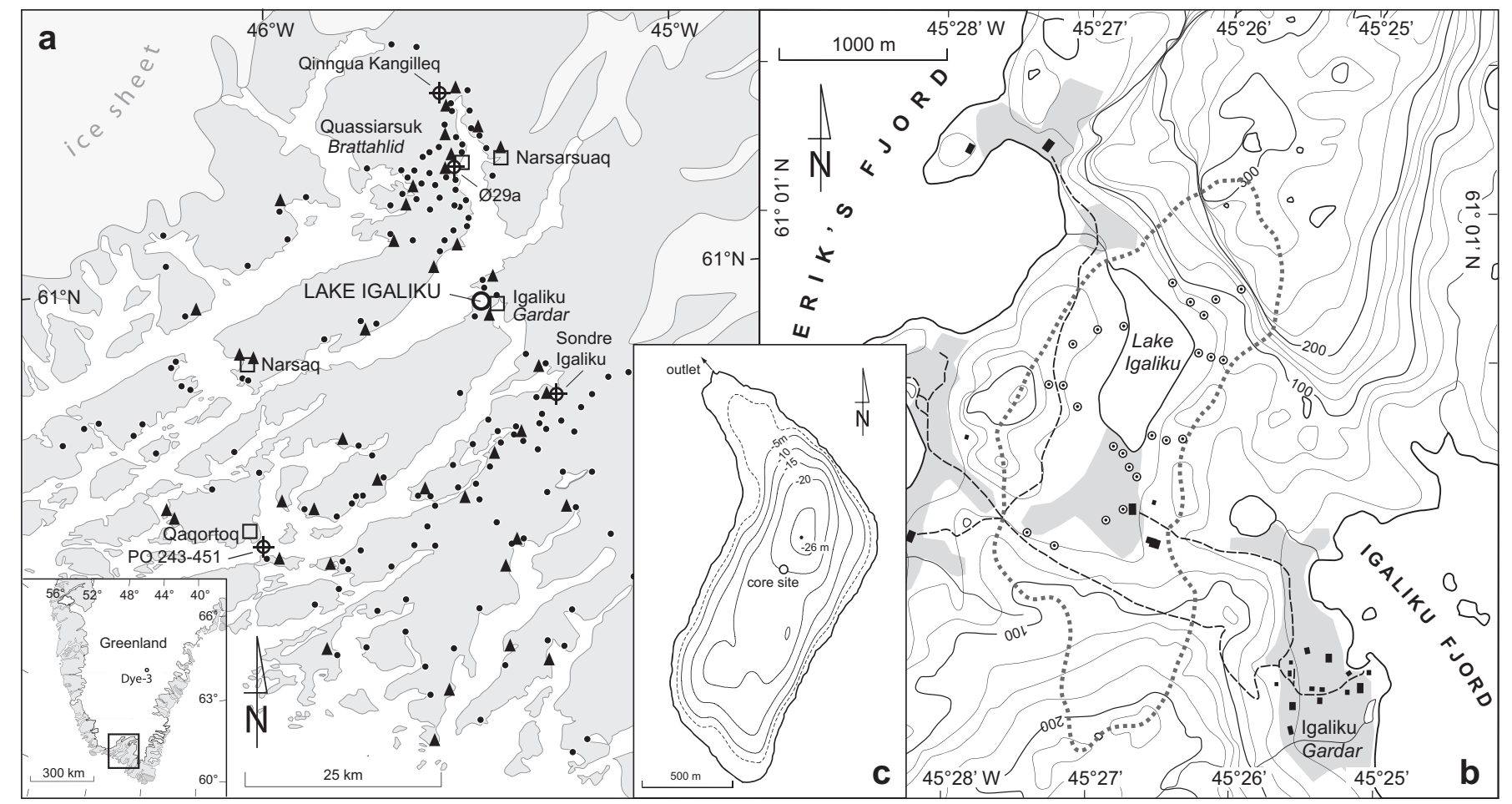

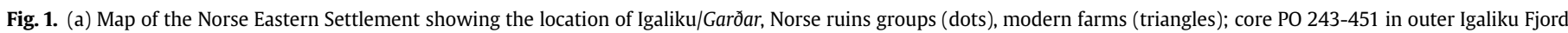

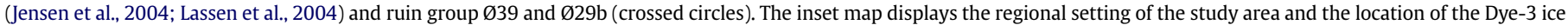

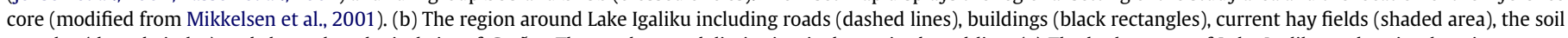
samples (dotted circles) and the archaeological site of Garðar. The catchment delimitation is drawn in dotted line. (c) The bathymetry of Lake Igaliku and coring location. 
The catchment area is $3.55 \mathrm{~km}^{2}$, without an inlet but a small outlet on the northern shore drains into the Tunulliarfik fjord. The local topography is characterized by a gently sloped large plain $\left(3.1 \mathrm{~km}^{2}\right)$ surrounded in the western part by a low rounded hill $(130 \mathrm{~m}$ asl). The slope is considerably steeper to the northeast were the highest relief reaches $300 \mathrm{~m}$ asl. The rocks underlying most of the catchment are Proterozoic granites of the Julianehåb batholith (Upton et al., 2003) that are partly covered by arkosic sandstones and lavas of the Mesoproterozoic Eriksford Formation which outcrops on the hills.

The study area is situated in the subcontinental, subarctic climatic and vegetational zone of southern Greenland (Feilberg, 1984). Toward the innermost and sheltered fjords, the climate gradually changes from maritime to more continental conditions reflected in the vegetation by an increase in dwarf-shrub heath or scrub which tends to cover most of the ground. The meteorological standard normals 1961-1990 (Cappelen et al., 2001) at the station of Narsarsuaq (17 km north of Igaliku, Fig. 1a) record a mean annual temperature of $0.9{ }^{\circ} \mathrm{C}$, with a maximum in July of $10-11^{\circ} \mathrm{C}, 194.8$ days/yr with frost and a yearly precipitation of $615 \mathrm{~mm}$. The area is windy, with a mean wind speed of $3.8 \mathrm{~m} / \mathrm{s}$, and strong desiccating foehn winds blowing from the Ice Cap are frequent year round.

\subsection{History of land use in the Igaliku area}

The town of Igaliku - the Norse Garðar - is located on a fertile plain at the head of Igaliku Fjord which lies strategically in the centre of the Eastern Settlement. According to the Groenlendinga Saga (Saga of the Greenlanders), the area was settled by the daughter of Erik the Red soon after the landnám (Gad, 1970; Jones, 1986). Garðar became the Episcopal seat of Greenland in 1124 AD, consecrated two years later by the arrival of the first bishop (Krogh, 1967). It is also thought to have been an assembly site of prime importance in the administrative system of Norse society (Sanmark, 2009). For these reasons Garðar was a high status farmstead: 52 Norse archaeological structures were recorded, including large byre-barn complexes, animal pens and enclosures, sheep/goat houses and an irrigation system attached to fodder production (Nørlund and Roussell, 1929). The bishop's farms could host over 100 head of cattle, in addition to goats and sheep (Christensen-Bojsen, 1991), probably making Garðar, by far, the largest holding of livestock in Norse Greenland. Buckland et al. (2009) showed paleoecological evidence for manuring and irrigation to enhance the productivity of Garðar's infields. As the 15 ha of land at Garðar where likely insufficient to raise a large livestock (Christensen-Bojsen, 1991), animals would have been kept from grazing in the infield and the total vegetated landscape of the area would have been utilized. This includes the catchment of Lake Igaliku, although neither ruins nor vestiges of fenced areas have been found.

The last bishop known to have resided at Garðar died in $1378 \mathrm{AD}$ (Arneborg, 2007) and the last written account attesting the presence of the Norse in Greenland is a letter dated from 1409 AD that announced a wedding at the Hvalsey church (Fig. 1a) the year before (Gad, 1970). These elements do not allow the exact timing of the abandonment to be determined, but it is generally accepted that it must have occurred sometime in the mid to late 15th century (Dugmore et al., 2009).

A Danish farmer settled the site of Garðar in the 18th century and a few domestic animals were kept in the region until the early 20th century (Arneborg, 2007). The modern grazing management began in 1915 with 250 sheep (Austrheim et al., 2008) and was intensified in 1924 under the impetus of the Danish government (Hansen, 1991). Until 1976, sheep farming was based on extensive all year round grazing, with small supplements of winter fodder and occasional stabling. The number of sheep in South Greenland increased up to a maximum of 47800 in 1966 but heavy snow and strong frost during the winter $1966 / 67$ starved to death nearly $60 \%$ of the herds. Similar disasters occurred in the winters of 1971/72 and 1976/77 (Greenland Agriculture Advisory Board, 2009). Consequently, a new plan for sheep management was presented (Egede, 1982): henceforth, sheep should graze 5 months on the outlying fields and be stall fed during the 7 months of the Greenland winters, requiring a considerable amount of fodder. Nowadays, there is one single farm in the catchment of Lake Igaliku and the lake surroundings are freely grazed by a few hundred sheep during the summer season. Two areas of land on the south and north shores of the lake are cultivated to produce winter fodder for stabling (Fig. 1b), on which $\mathrm{N}$ fertilizer are deployed (200-250 kg ha-1 $\mathrm{yr}^{-1}$ of $\mathrm{N}$, Miki Egede, personal communication). Also, a small stream drains effluent from the barn into the nearby lake.

\section{Methods}

\subsection{Fieldwork}

A 4 m-long sediment succession was sampled from the centre of Lake Igaliku (Fig. 1c) using gravity and piston corers equipped with Ø $63 \mathrm{~mm}$ PVC liners (both from UWITEC Co., Austria). The sediment water interface was properly recovered by using the gravity corer (Wagner et al., 2008). The sequence spans the entire post glacial history (ca. 10000 yrs) but only the top $120 \mathrm{~cm}$ are presented here. Twenty five volumetric samples of near-surface soils (upper $5 \mathrm{~cm}$ ) were taken in the catchment of Lake Igaliku to determine dry bulk density (Fig. 1b). The soil samples were processed for loss on ignition at $550{ }^{\circ} \mathrm{C}$ to calculate the bulk mineral content (BMC). An average BMC of $420 \mathrm{mg} \mathrm{cm}^{3}$ was estimated for the whole catchment.

\subsection{Non destructive laboratory analyses}

An X-ray radiography was obtained using the Scopix system (Migeon et al., 1999) followed by laboratory X-Ray Fluorescence (XRF) core scanner measurements (Avaatech, Netherlands). Analysis was continuously performed every $2 \mathrm{~mm}$ with a counting time of $30 \mathrm{~s}$ and a $10 \mathrm{kV}$ acceleration intensity. Because the sediment matrix is characterized by variable water content and grain size distributions the XRF scanner only provides a relative estimation of geochemical variables (e.g. Tjallingii et al., 2007). A normalization of element counts to the total count numbers was operated because it may partially correct drifts (Revel et al., 2010). The relative opal content was assessed using XRF-derived Si:Ti ratio (Peinerud et al., 2001) and compared to diatom valve concentrations (see Perren et al., in press, for methodological details).

\subsection{Sampling method}

The top $10 \mathrm{~cm}$ were sampled in $0.5 \mathrm{~cm}$ slices and below $10 \mathrm{~cm}$, sampling intervals were chosen by using the X-ray image to ensure that the varying lithology is well represented and to provide homogenous samples. The subsamples (157) were separated into different sets. Volumetric samples $\left(1 \mathrm{~cm}^{3}\right)$ were taken with cut plastic syringes, weighed and kept cold for biological analysis (Perren et al., in press; Gauthier et al., 2010). The others were gently dried at $60^{\circ} \mathrm{C}$ until constant weight to obtain sediment water content (WC, w/w). The dried sediment was ground to $<63 \mu \mathrm{m}$ with an agate ball micromiller (Retsch, Germany) and homogenized.

\subsection{Organic matter, elemental and isotopic analyses}

The total organic nitrogen and carbon (TOC) concentrations were determined with a vario MAX CNS analyser (Elementar, 
Germany) using $\sim 170 \mathrm{mg}$ of dried material. The large sample size led to a relative standard error $<1 \%$ for both elements. A subset of 25 samples were also measured for loss on ignition (LOI) at $550{ }^{\circ} \mathrm{C}$ and $950^{\circ} \mathrm{C}$ to estimate organic matter content (OM), carbonate mineral content and mineral matter content (MM) in sediments (Santisteban et al., 2004). TOC and $\mathrm{LOI}_{550^{\circ} \mathrm{C}}$ appeared to be strongly correlated $\left(\mathrm{LOI}_{550^{\circ} \mathrm{C}}=2.3 \times \mathrm{TOC}, R^{2}=0.99, p<0.001\right)$. Using this regression (slope $=2.3)$, OM and $\mathrm{MM}(100-\mathrm{OM})$ were estimated on the whole sample set.

About $6 \mathrm{mg}$ of dried sediment of the upper $75 \mathrm{~cm}(n=104)$ were loaded in tin capsules and the stable isotopic composition of organic carbon and total nitrogen was determined on an elemental analyser NA 1500 NCS (Carlo Erba Instruments, Milan, Italy) coupled in continuous flow mode to a stable isotope ratio mass spectrometer VG Isochrom (Micromass, Manchester, England). No significant loss of weight at $950{ }^{\circ} \mathrm{C}$ revealed that carbonate content is negligible for the Igaliku samples. Therefore, the sedimentary carbon is assumed to be organic and no removal of carbonate carbon was necessary before $\delta^{13} \mathrm{C}$ measurements. All subsamples were triplicated and the $95 \%$ confidence interval of the mean is reported. Results are expressed in standard delta notation.

\subsection{ICP-AES geochemistry and calibration of XRF scanner results}

Fifty six samples were processed for inductively coupled plasma-atomic emission spectrometry (ICP-AES) measurements. About $70 \mathrm{mg}$ of accurately weighed sediment were totally dissolved under pressure on a hotplate using a mixture of $1 \mathrm{~mL}$ each suprapure grade $\mathrm{HCl}, \mathrm{HNO}_{3}$ and $\mathrm{HF}$ (Merck, Germany). After evaporation, the residues were retaken with $\mathrm{HNO}_{3}$ and appropriately diluted with MilliQ water. Certified reference material (BCR-2, BCSS-1, JSD1, PACS-1) and 3 duplicates were added to the set of samples. The error of Ti concentration did not exceed $\pm 8 \%$. XRF-normalized $\mathrm{Ti}$ contents closely follow those obtained by ICP-AES $(r=0.83, n=53$, $p<0.001$ ). Linear regression parameters were used to estimate $\mathrm{Ti}$ content along the whole section.

\subsection{Core chronology}

The age control of the upper $120 \mathrm{~cm}$ of the Igaliku core is based on 18 Atomic Mass Spectrometry (AMS) ${ }^{14} \mathrm{C}$-measurements on handpicked and mechanically cleaned plant remains (Table 1, Fig. 2a), carried out at the Poznań Radiocarbon Laboratory (Poland) and at the
Lyon Radiocarbon Laboratory (France). The bryophyte date at $66.3-67.3 \mathrm{~cm}$ is 310 years too old compared to the result of the two terrestrial macrofossils that closely surround it. This phenomenon is due to a particular reservoir effect which affects arctic lakes due to the in-lake recycling of carbon (Abbott and Stafford, 1996). Thus a reservoir correction of 310 years was applied to all ${ }^{14} \mathrm{C}$ age of aquatic mosses before calibration (e.g. Kaplan et al., 2002; Klug et al., 2009).

The chronology for the last 150 years was established with ${ }^{210} \mathrm{~Pb}$ and ${ }^{137} \mathrm{Cs}$ dating (Fig. 2b). The 20 samples from the top $10 \mathrm{~cm}$ of the core ( $\sim 2 \mathrm{~g}$ of dried sediment) were measured for ${ }^{137} \mathrm{Cs}$ activity by gamma spectrometry in a calibrated geometry using a high-purity Ge well-type detector. The total ${ }^{210} \mathrm{~Pb}$ activity of the top $16.4 \mathrm{~cm}$ (14 contiguous samples $1.0-1.6 \mathrm{~cm}$ each) was measured using alpha spectroscopy at MyCore Scientific Inc. in Ontario, Canada. Ages were determined using the constant rate of supply (CRS) model, which assumes a constant rate of unsupported ${ }^{210} \mathrm{~Pb}$ from atmospheric fallout but allows sediment accumulation to vary (Appleby and Oldfield, 1978). The supported activity was determined from the basal section of ${ }^{210} \mathrm{~Pb}$ data (Fig. $2 \mathrm{~b}$ ).

Results from radiocarbon and short-lived radio-isotopes were combined to produce an age-depth model for the whole sequence using a smooth cubic spline model and following the Monte Carlo approach provided by Blaauw (2010). This method ('Clam') allows robust uncertainties to be computed and takes into account the entire probability distribution of the calibrated radiocarbon dates, avoiding any arbitrary choice.

\subsection{From sediment accumulation rate to soil erosion}

The sediment accumulation rate (SAR, expressed in $\mathrm{cm} \mathrm{yr}^{-1}$ ), as well as its uncertainty, was computed by adapting the 'Clam' function to calculate the first derivative of the n-bootstrapped agedepth models and then, from these multiple SAR, the weighted average and 95\% confidence interval. Then, mass accumulation rates of organic and minerogenic matter were calculated as follows:

$$
\begin{aligned}
& \text { MAR }_{\mathrm{org}}\left[\mathrm{mg} \mathrm{cm}^{-2} \mathrm{yr}^{-1}\right]=\mathrm{WBD} \cdot(1-\mathrm{WC}) \cdot \mathrm{OM} \cdot \mathrm{SAR} \\
& \mathrm{MAR}_{\min }\left[\mathrm{mg} \mathrm{cm}{ }^{-2} \mathrm{yr}^{-1}\right]=\mathrm{WBD} \cdot(1-\mathrm{WC}) \cdot \mathrm{MM} \cdot \mathrm{SAR}
\end{aligned}
$$

WBD being the wet bulk density $\left(\mathrm{mg} \mathrm{cm}^{-3}\right)$ assessed using WC, OM and MM (Sugai et al., 1994). Using the obtained MAR $\min$, an

Table 1

\begin{tabular}{|c|c|c|c|c|c|c|c|}
\hline \multirow{2}{*}{$\begin{array}{l}\text { Depth }(\mathrm{cm}) \\
3.5-4.5\end{array}$} & \multirow{2}{*}{$\begin{array}{l}\text { Material } \\
\text { Undetermined plant remains }\end{array}$} & \multirow{2}{*}{$\begin{array}{l}\text { Lab code } \\
\text { Poz-24707 }\end{array}$} & \multirow{2}{*}{$\begin{array}{l}\text { C yr BP }( \pm 1 \sigma) \\
* 107.11 \pm 0.36\end{array}$} & \multirow{2}{*}{$\begin{array}{l}\text { Corrected } \\
{ }^{14} \mathrm{C} \text { age } \\
-\end{array}$} & \multicolumn{2}{|c|}{ Cal $\mathrm{BC} / \mathrm{AD}(2 \sigma$ range $)$} & \multirow{2}{*}{$\begin{array}{l}\text { Cal BC/AD } \\
\text { (weighed mean) } \\
-\end{array}$} \\
\hline & & & & & $\mathrm{AD}$ & 1956 minimum & \\
\hline $17.4-17.7$ & Aquatic moss & Poz-31628 & $680 \pm 100$ & 370 & $\mathrm{AD}$ & $1395-1950$ & 1559 \\
\hline $27.5-28.5$ & Betula leaf & Poz-31632 & $620 \pm 80$ & - & $\mathrm{AD}$ & $1265-1435$ & 1347 \\
\hline $30.0-30.7$ & Betula bark fragment & Poz-31629 & $655 \pm 35$ & - & $\mathrm{AD}$ & $1280-1395$ & 1337 \\
\hline $32.6-33.6$ & Salix leaf & Poz-26852 & $775 \pm 30$ & - & $\mathrm{AD}$ & $1215-1280$ & 1248 \\
\hline $39.9-40.7$ & Twig & Poz-31630 & $945 \pm 35$ & - & $\mathrm{AD}$ & $1020-1165$ & 1095 \\
\hline $51.5-52.5$ & Wood & Poz-35136 & $1005 \pm 30$ & - & $A D$ & $980-1150$ & 1035 \\
\hline $60.7-61.7$ & 1 Salix and 2 Betula leaves & Poz-38952 & $1260 \pm 40$ & - & $\mathrm{AD}$ & $670-870$ & 753 \\
\hline $66.3-67.3$ & Aquatic moss & Poz-30535 & $1570 \pm 35$ & 1260 & $\mathrm{AD}$ & $670-865$ & 749 \\
\hline $67.1-67.3$ & Wood & Lyon-7300 & $1265 \pm 30$ & - & $\mathrm{AD}$ & $665-860$ & 739 \\
\hline $67.9-68.1$ & Wood & Lyon-7301 & $1410 \pm 30$ & - & $\mathrm{AD}$ & $595-665$ & 631 \\
\hline $68.8-69.8$ & Twig & Poz-35135 & $1305 \pm 30$ & - & $\mathrm{AD}$ & $660-770$ & 712 \\
\hline $71.0-71.7$ & Betula leaf & Lyon-7302 & $1450 \pm 30$ & - & $A D$ & $565-650$ & 609 \\
\hline $78.6-79.8$ & Leaf & Poz-31633 & $1580 \pm 60$ & - & $\mathrm{AD}$ & $345-605$ & 480 \\
\hline $89.0-90.0$ & Betula wood & Lyon-31874 & $1775 \pm 40$ & - & $\mathrm{AD}$ & $135-380$ & 256 \\
\hline $94.2-94.6$ & Betula wood & Lyon-7303 & $1930 \pm 30$ & - & $\mathrm{AD}$ & $5-130$ & 73 \\
\hline $112.5-113.5$ & Betula leaves fragments & Poz-37363 & $2250 \pm 40$ & - & $\mathrm{BC}$ & $395-205$ & -297 \\
\hline $125.8-126.8$ & Aquatic moss & Poz-30536 & $2930 \pm 70$ & 2620 & $\mathrm{BC}$ & $925-540$ & -757 \\
\hline
\end{tabular}

Radiocarbon dates from the sediment archive of lake Igaliku. The post-bomb radiocarbon activity (marked*) is expressed as a percentage of modern carbon (pmC). 


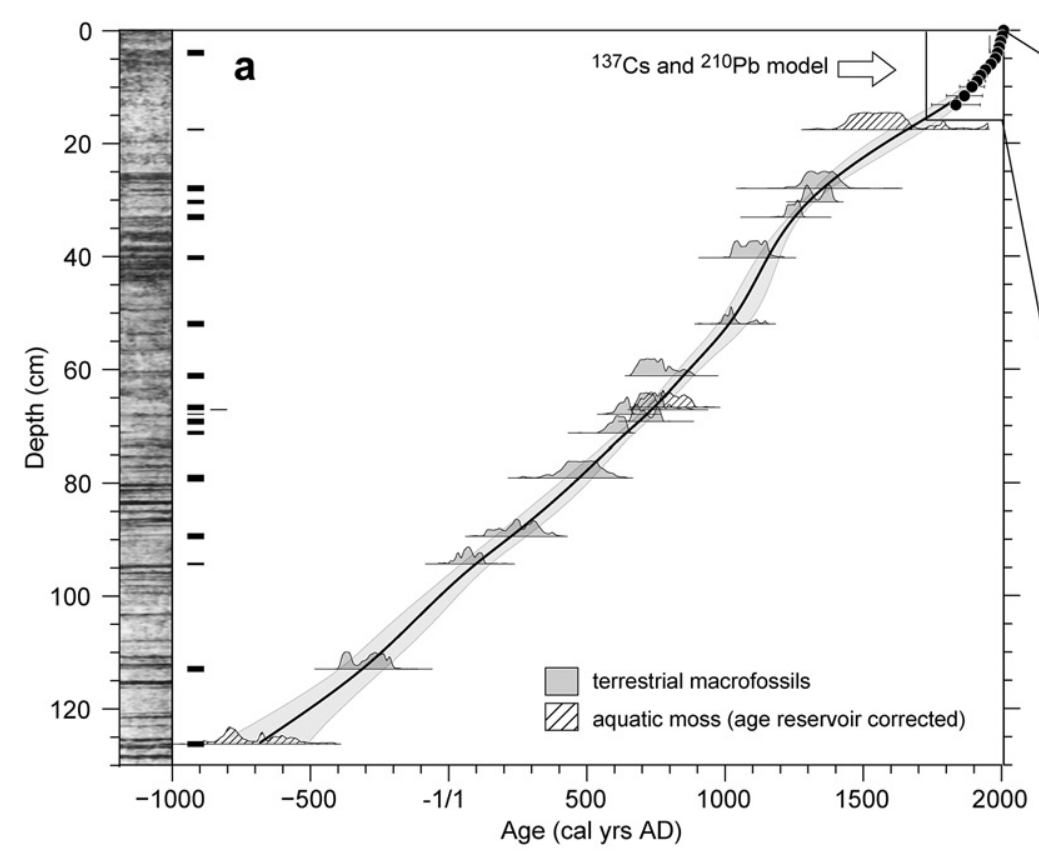

${ }^{137} \mathrm{Cs}$ activity $(\mathrm{Bq} \mathrm{kg}-1)$

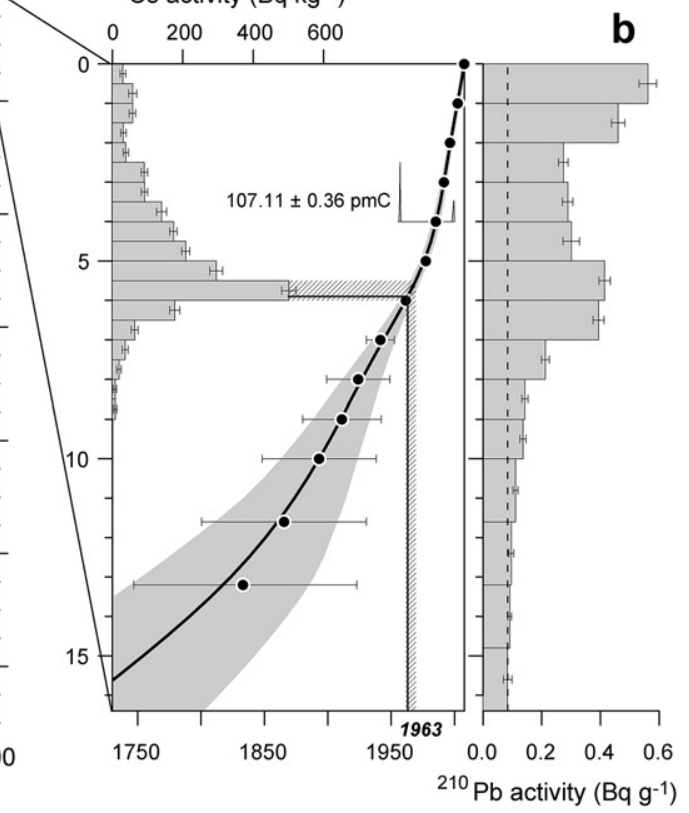

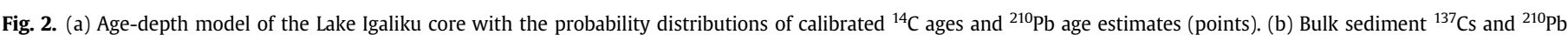

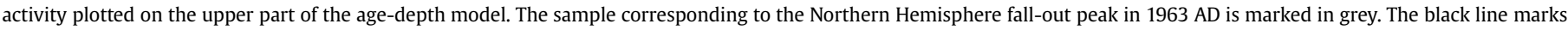
$1963 \mathrm{AD}$ from the age depth model. Horizontal error bars are expressed as $95 \%$ confidence level.

estimation of soil erosion through the calculation of a mean denudation rates (DR) is proposed, basically assuming that the sediment is equally distributed on the entire surface area of the lake (Enters et al., 2008) and with a bulk mineral content (BMC) of $420 \mathrm{mg} \mathrm{cm}^{-3}$ for eroded soil (surface horizon):

$\mathrm{DR}\left[\mathrm{mm}\right.$ century $\left.^{-1}\right]=\mathrm{MAR}_{\mathrm{min}} \cdot$ lake area/

catchment area/BMC $\cdot 1000$

\section{Results}

\subsection{Lithology and chronology}

The upper $130 \mathrm{~cm}$ of the lake Igaliku core are composed of very finely stratified brownish sandy silt with black horizons rich in ferrous iron oxide. From $\sim 5 \mathrm{~cm}$, the sandy silts give way to black clayey silts until water-sediment interface. The X-radiographs reveal a continuous sedimentation with distinct lamina $(\sim 6 \mathrm{~mm})$, indicating that sediments were not continuously mixed by bioturbation.

The age-depth model is almost linear until $\sim 1010$ AD (Fig. 2a) with a mean SAR of $\sim 0.4 \mathrm{~mm} \mathrm{yr}^{-1}$. Then, the SAR continuously rises to a maximum of $0.8 \mathrm{~mm} \mathrm{yr}^{-1}$, around $1150 \mathrm{AD}$, and decreases gradually after that date. A sharp increase in the SAR, up to $1.9 \mathrm{~mm} \mathrm{yr}^{-1}$, is noted during the 20th century. Six AMS dates were targeted before $1000 \mathrm{AD}$ to reduce the uncertainty resulting from a plateau in the calibration curve around the landnám period (Dugmore et al., 2005). The narrower uncertainty of the ${ }^{14} \mathrm{C}$ part of the model is obtained for the period $1200-1350 \mathrm{AD}$ ( $\pm 25 \mathrm{yr}$ ) with 3 closely spaced dates whereas the ${ }^{210} \mathrm{~Pb}$ part of the model is very accurate with an error that range between \pm 25 to $1.5 \mathrm{yr}$ for the 20th century (Fig. 2b).

The ${ }^{137} \mathrm{Cs}$ peak at $5.5-6.0 \mathrm{~cm}$ depth $\left(500 \mathrm{~Bq} \mathrm{~kg}^{-1}\right)$ clearly represents the main fall-out peak of 1963 AD in the Northern Hemisphere due to atmospheric nuclear weapon tests (Pennington et al., 1973) and is in agreement with the ${ }^{210} \mathrm{~Pb}$ CRS model (Fig. 2b). The low ${ }^{137}$ Cs activity measured before the 1950s can be explained by a slight downward diffusion of the radionuclide in the sediment. The ${ }^{14} \mathrm{C}$ date at $4 \mathrm{~cm}$ (Poz-24707, Table 1$)$ gives a clear post-bomb radiocarbon activity of $107.11 \pm 0.36 \mathrm{pmC}$ (Fig. 2b). Calibrated with the Bomb04NH1 calibration curve of Hua and Barbetti (2004), it gives a minimum age of $\mathrm{AD} 1956$ which fits with the ${ }^{210} \mathrm{~Pb}$ model.

\subsection{Mass accumulation rates and sediment composition}

As there is no marked change in the sediment composition (Fig. 3), the SAR controls $89 \%$ and $97 \%(n=157, p<0.001)$ of the total minerogenic and organic MAR variance respectively. Thus, error in MAR is mainly due to lack of accuracy in the core chronology. The two major increases in sediment supply, toward 1150 $\mathrm{AD}$ and at end in the 20th century, are characterized by the highest levels of OM with $16 \%$ and $19 \%$ respectively.

The inferred contribution of biogenic silica is positively proportioned to the diatoms concentration (Fig. 3). There is no significant linear relationship between diatom concentration and MM $(r=-0.02, n=114, p=0.80)$ indicating that most of the silica in the sediment is of mineral source. The diatom concentration is inversely proportioned to $\mathrm{MAR}_{\min }$, except for the uppermost part of the core where the two parameters reach their maximum values of $74 \mathrm{mg} \mathrm{cm}^{-2} \mathrm{yr}^{-1}$ and $50 \times 10^{9}$ valves $\mathrm{g}^{-1}$ (Fig. 3). However, these high diatom concentrations do not increase the opal content as they are mainly due to a sharp increase in Cyclotella stelligera, a small species, which constitute $\sim 60 \%$ of the diatom assemblage on this part of the core (Perren et al., in press).

\subsection{Geochemical profiles}

The Ti profile remains relatively stable before $1010 \mathrm{AD}$ with an average value of $3200 \mathrm{ppm}$ (Fig. 4). The concentration increases then up to $4400 \mathrm{ppm}$ with peak values between $1010 \mathrm{AD}$ and $1335 \mathrm{AD}$. Then, Ti concentrations fall to an average of $3650 \mathrm{ppm}$, which is $14 \%$ more than the pre-landnám baseline. Above $\sim 1960$ AD the titanium 


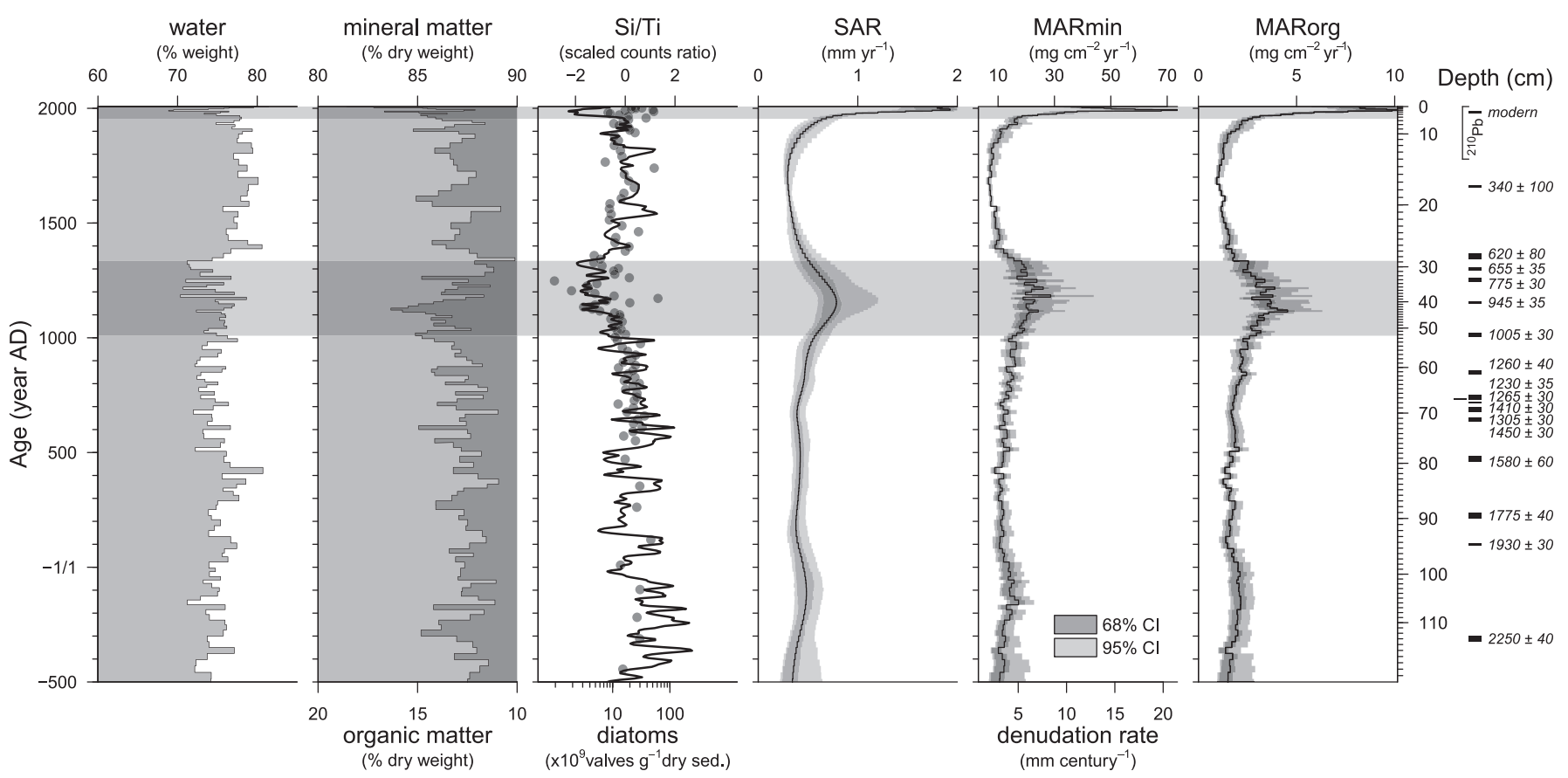

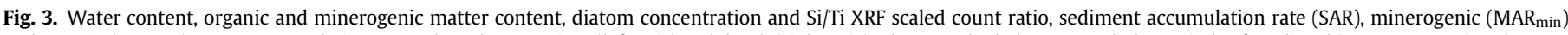

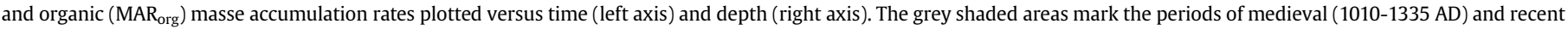
(after $1960 \mathrm{AD}$ ) agricultural impacts recorded in the Igaliku core.

content increases sharply to reach the maximum values of the profile around $4600 \mathrm{ppm}$. C:N ratio coevals greatly with Ti content both for general trends and decadal scale variations, but unlike Ti, the C:N ratio does not show significantly higher values in the period of 1335-1960 AD than before 1010 AD (Student's $t$ test, $p=0.28$ ). The four uppermost samples, after $1997 \mathrm{AD}$, are clearly outlying the general geochemical composition of organic matter, and exhibit high $\delta^{15} \mathrm{~N}$, low C:N ratios and low $\delta^{13} \mathrm{C}$ values (Fig. 5ab). Except for these samples, a strong linear and negative relationship links the $\mathrm{C}: \mathrm{N}$ ratio and the bulk $\delta^{13} \mathrm{C}(r=-0.80, n=104, p<0.001)$ (Fig. 5b). The relationship between $\delta^{13} \mathrm{C}$ and $\delta^{15} \mathrm{~N}$ is more complicated: the two isotope ratios are negatively correlated $(r=-0.73, n=84, p<0.001)$, except for the period 1030-1230 AD during which the correlation is strongly positive $(r=0.78, n=20, p<0.001)$ (Fig. 5a).

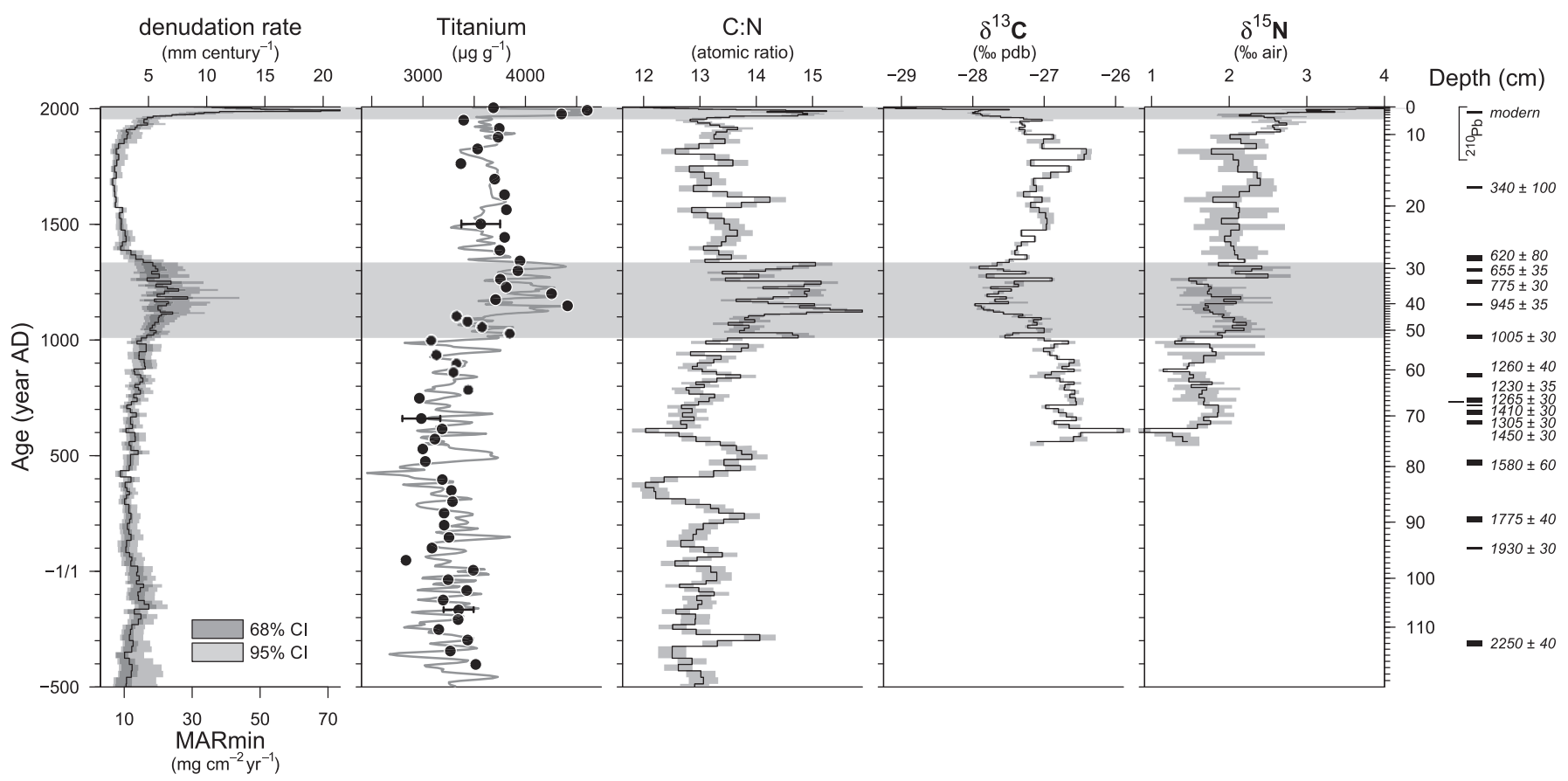

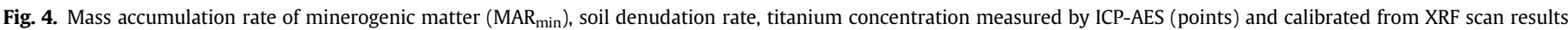
(curve), $\mathrm{C}: \mathrm{N}$ atomic ratio, $\delta^{13} \mathrm{C}$ and $\delta^{15} \mathrm{~N}$ of bulk organic matter from the last 2500 years of the sediment archive of lake Igaliku. 


\subsection{Assessing soil erosion}

The calculated detritic inflows can be biased and overestimated by the presence of autochthonous silica. Especially when considering that in Greenland lakes, biogenic silica can contribute up to 35\% of the total minerogenic matter content and can explain more than $40 \%$ of its variance (Willemse, 2002). However the absence of significant relationship between MM and diatom concentration indicates that changes in allochthonous MM (linked to soil erosion) drive the total MM fluctuations at the Igaliku Lake. Moreover, the lower diatom concentrations coincide with the periods of maximum sediment yield around 1010-1335 AD and after 1960 AD which clearly indicate that opal production is diluted by the detritic inputs.

The titanium is a conservative lithogenic element that participates in very few biogeochemical processes (Kauppila and Salonen, 1997; Koinig et al., 2003). So the shifts to higher Ti concentrations in the sediment points to enhanced physical weathering of alumino-silicates in the watershed that can be climatic or due to land use (Kylander et al., 2011). Bulk sediment C:N ratios are widely used in palaeolimnology for assessing the abundance of terrestrial and aquatic components of organic matter (eg. Kaushal and Binford, 1999). For Igaliku, C:N ratios between 11.5 and 16 indicate a mixture of lacustrine and terrestrial contribution to the
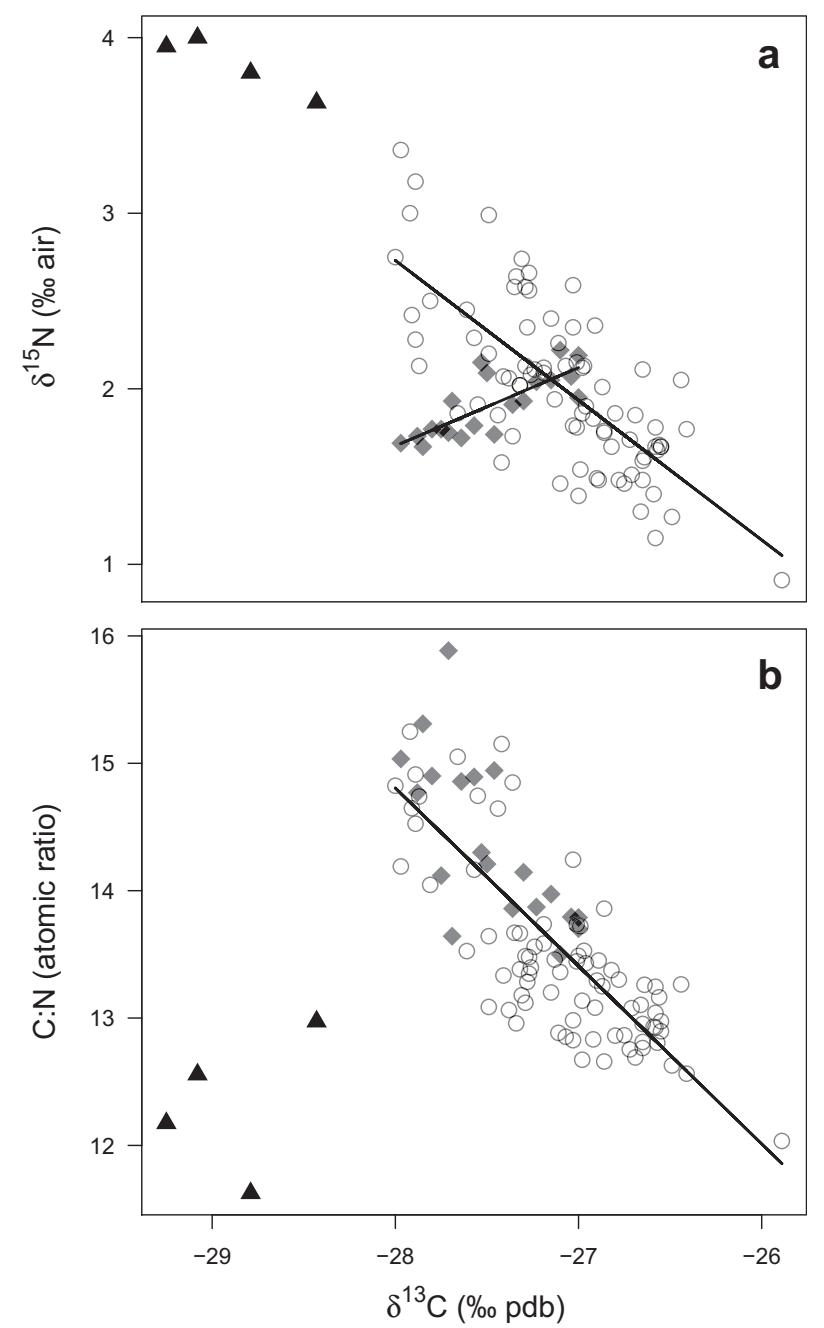

Fig. 5. (a) Cross-plot of $\delta^{15} \mathrm{~N}$ and $\delta^{13} \mathrm{C}$. The isotopic ratios are negatively correlated $(r=-0.73)$ except for the period 1030-1230 AD (grey diamonds) where the correlation is positive $(r=0.78)$. (b) Cross-plot of $\mathrm{C}: \mathrm{N}$ ratio and $\delta^{13} \mathrm{C}$. The filled triangles represent the outliers from 1997 to 2007 AD. organic matter pool (lacustrine plants $\sim 6-9$, land plants $\geq 20$; Meyers and Ishiwatari, 1993). Values above 14 during the period 1010-1335 AD and after 1960 indicate increases in terrestrial OM input and suggest soil erosion. The consistency of Ti and $\mathrm{C}: \mathrm{N}$ demonstrate that they constitute two robust proxy of soil erosion and strengthen the significance of the two detritic events described above. It appears that the geochemical parameters provide a very high resolution, but relative, view of soil erosion, whereas the $\mathrm{MAR}_{\text {min }}$ give an absolute, but smoothed estimate.

Changes in organic matter supplies are also mirrored in the isotopic composition of carbon and nitrogen. The $\delta^{13} \mathrm{C}$ of organic carbon produced photosynthetically is enriched with increases in primary production and is used as a proxy for lacustrine productivity (Schelske and Hodell, 1995). However, for the Igaliku core, the strong negative correlation between $\delta^{13} \mathrm{C}$ and $\mathrm{C}: \mathrm{N}$ ratio indicates that the isotopic composition of bulk organic carbon is principally influenced by changes in terrestrial organic matter supplies. Although $\mathrm{N}$ utilization associated with productivity variations have been considered the most common cause of changes in sediment $\delta^{15} \mathrm{~N}$ (e.g. Jinglu et al., 2007), $\mathrm{N}$ isotopes are affected to a greater extent by food chain dynamics than are C isotopes (Hodell and Schelske, 1998) and external $\mathrm{N}$ inputs from sewage, fertilizers or soil erosion can also contribute to it (Teranes and Bernasconi, 2000; Talbot, 2002; Lu et al., 2010). Thus, $\delta^{15} \mathrm{~N}$ values are likely controlled both by in-lake mechanisms and allochthonous sources. That may explain its different pattern from that of $\delta^{13} \mathrm{C}$.

\section{Discussion}

\subsection{Natural variability of soil erosion before the Norse arrival (500 $B C-986 A D$ )}

The lake Igaliku sediment record documents large fluctuations in mass accumulation rates and geochemical parameters that are consistent with meaningful changes in soil erosion regime. These results can be linked to climate variations and to human activities for the last 2500 years.

The DR is stable for the period $500 \mathrm{BC}-986 \mathrm{AD}$ and ranges between 2.5 and $5 \mathrm{~mm}$ century $^{-1}$ (Fig. 6a). The main feature of the Igaliku profiles for this period is the large oscillation in $\mathrm{Ti}, \mathrm{C}: \mathrm{N}$ ratio and Si:Ti ratio between 100 and $600 \mathrm{AD}$ which indicate changes in the balance between detritic inputs and in-lake productivity (Fig. 4). The high detritic inputs and low productivity around $250 \mathrm{AD}$ suggests a cooling which corresponds to relatively low temperatures in the Arctic between 165-345 AD (Kaufman et al., 2009). The low $\mathrm{C}: \mathrm{N}$ and Ti values at $\sim 400 \mathrm{AD}$ indicate low erosion and/or high algal productivity which could be linked to a warm climate. This period is indeed coeval with almost the warmer time interval (375-415 AD) recorded in the Arctic for the last 2000 years (Kaufman et al., 2009). The most detritic period in at 470-550 AD roughly corresponds to a major cooling in the North Atlantic (Bond, 1997) and in the Igaliku Fjord waters (Jensen et al., 2004; Lassen et al., 2004) at 550-650 AD. On the winter $\delta^{18} \mathrm{O}$ curve of the Dye- 3 ice core (Vinther et al., 2010), which is the closest available glacial record (Fig. 1a), this cold period culminates around $650 \mathrm{AD}$. The slight discrepancy between the records could be explained by the littoral position of Lake Igaliku which is more influenced by oceanic surface currents than the Dye-3 location (Andresen et al., 2004).

\subsection{Impacts of medieval farming (ca. 1010-1335 AD)}

The Norse arrived during the relatively warm temperatures of the Medieval Climate Anomaly (Fig. 6b), temperatures that are comparable to those of the 1920s (Vinther et al., 2010). Warm temperatures in the early 11 th century results in a reduction of seasonal ice cover in the Igaliku Fjord (Roncaglia and Kuijpers, 

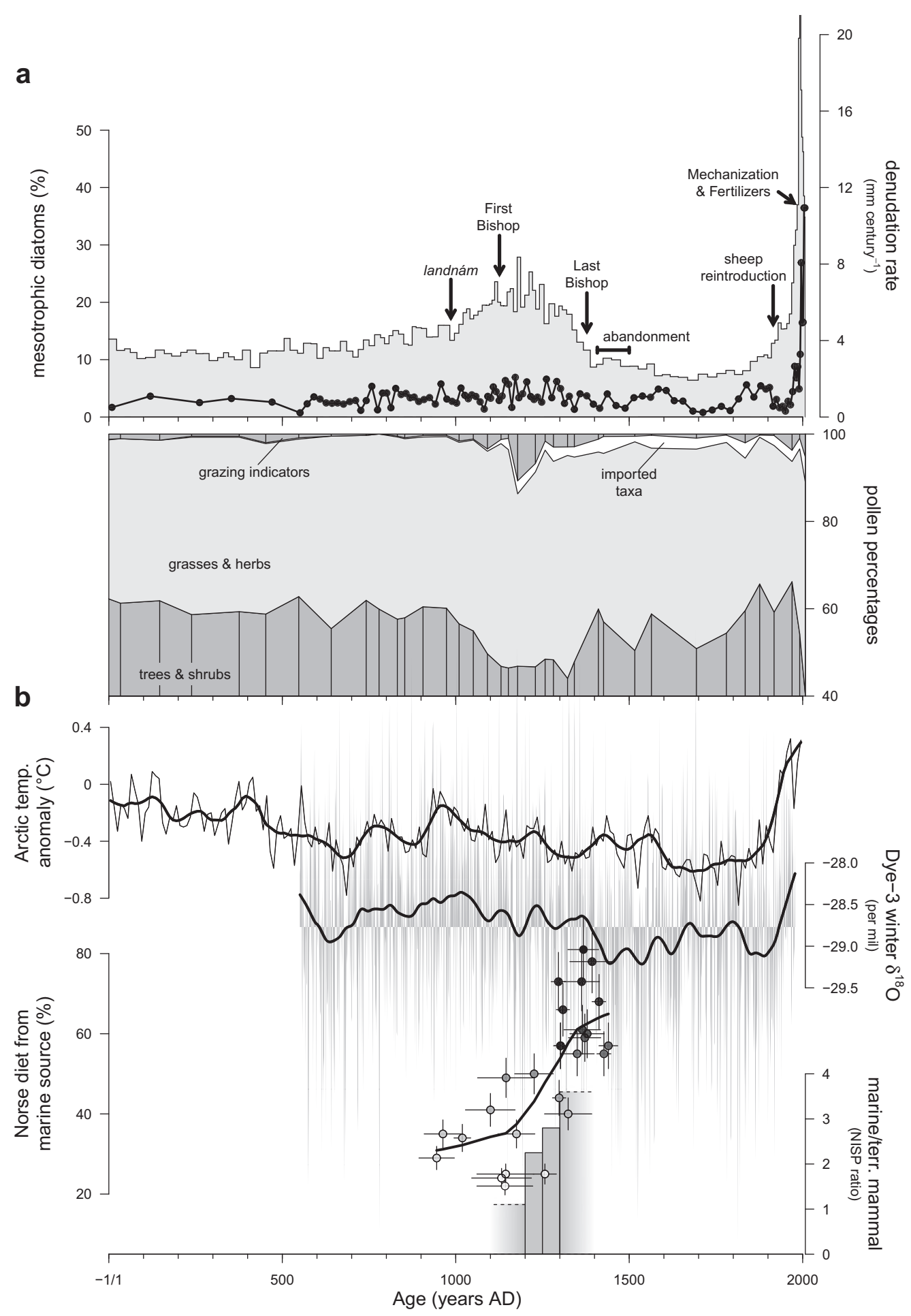

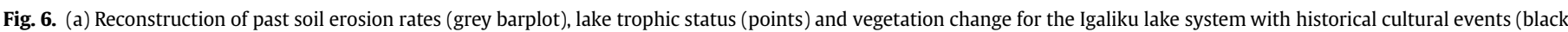

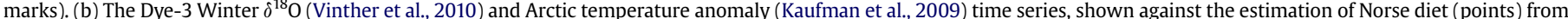

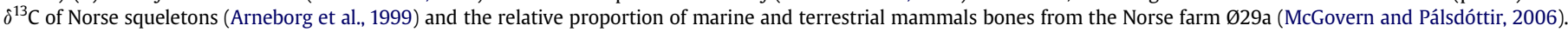
This figure was inspired by the work of Dugmore et al. (2009).

2004) indicating an extension of the growing season which was favorable to Norse farming. Thus, compared with the relatively stable soil erosion rate before the Norse landnám, its increase during the period 1010-1335 AD is interpreted as a consequence of agricultural activities in the lake catchment. Soon after the Norse arrival, the land clearance (indicated in pollen data by a decrease in woody taxa) and the introduction of sheep led to a rapid increase in soil erosion to a maximum of $8 \mathrm{~mm}$ century $^{-1}$ around $1180 \mathrm{AD}$, twice the background level (Fig. 6a). The positive phase of correlation between $\delta^{13} \mathrm{C}$ and $\delta^{15} \mathrm{~N}$ between 1030 and $1230 \mathrm{AD}$ as well as maximum values in $\mathrm{C}: \mathrm{N}$ ratio and Ti suggest a stronger impact of Norse farming during this period (Fig. 5a). Maximum erosion 
appears a few decades after the appointment of the first bishop when Garðar was probably close to its maximum development and activity (Fig. 6a). First land-use erosion around Lake Igaliku also precedes by 100 years the formation of an anthropogenic soil horizon at Garðar between 1110-1370 AD (Buckland et al., 2009) and constitute the older evidence of human impact on the area.

Soil erosion is perfectly synchronized with the grazing pressure recorded by the amount of coprophilous fungal spores (grazing indicators, Fig. 6a) which are typically found on animal dung (Gauthier et al., 2010). The grazing pressure and associated soil erosion still remain high until $1335 \mathrm{AD}$ with high levels and large amplitude fluctuations of the $\mathrm{C}: \mathrm{N}$ ratio indicating a destabilization of soils in the watershed (Fig. 4). Surface horizons of Garðar's soils are high in organic matter $(\sim 25 \%)$ because of the short growing and decomposition periods (Rutherford, 1995). Thus, erosion of surface horizons could result in a rapid increase in soil organic matter input that could explain the simultaneous increase of OM accumulation rates and high sediment organic contents (Fig. 3) as well as the marked changes in elemental and isotopic composition of OM (Figs. 4 and 5). Indeed, although allochthonous input does not seem to have caused substantial changes in trophic status of the lake, indicated by a relatively stable abundance in mesotrophic diatoms (Perren et al., in press, Fig. 6a), a reversed slope in linear relationship between $\mathrm{C}$ and $\mathrm{N}$ isotopes has already been observed in Lake Ontario and interpreted as a change in phosphorus loading to the basin (Hodell and Schelske, 1998). At Igaliku, high inflows of soil organic matter made the sediment composition remain relatively stable during erosion phases. Other sedimentary sequences, close to the archaeological remains, may have recorded a more localized and intense erosion which was able to cause noteworthy change in the sediment composition (Sandgren and Fredskild, 1991; Edwards et al., 2008; Schofield et al., 2008; Buckland et al., 2009; Schofield et al., 2010).

After $1335 \mathrm{AD}$, the grazing pressure decreased as indicated by a return of coprophilous fungal spores to pre-landnám background values (Gauthier et al., 2010). At the same time the dwarf-shrub community recovered and soil erosion level decreased to reach pre-anthropogenic values (Fig. 6a). Our data indicate a substantial decline of agro-pastoral practices around the lake of Igaliku well before the end of the Norse Eastern Settlement. This decline occurred a few decades before the death of the last bishop known to have lived at Garðar (Fig. 6a) suggesting that the activity was already reduced before this historical evidence of decline.

\subsection{Adaptation versus destruction}

Land degradation and mass erosion leading to a serious decline in agricultural yield is supported by many authors (e.g. Gad, 1970; Jacobsen and Jakobsen, 1986; Jacobsen, 1987; Fredskild, 1988; McGovern et al., 1988; Jakobsen, 1991; Fredskild, 1992; Diamond, 2005; Edwards et al., 2008; Schofield and Edwards, 2011). Coupled with worsening climate conditions of the 'Little Ice Age' and the refusal to drastically change their sedentary lifestyle, what Barlow et al. (1997) called 'cultural intransigence', the overexploitation of the environment would have been a major cause of the collapse of the medieval Norse society in Greenland. Archaeology nonetheless provides evidence that might oppose this theory. The Norse were only partly dependent upon agriculture (Krogh, 1967) and studies of the archaeofauna from several Norse farms have demonstrated a change of the dietary habits giving more and more importance to hunting, especially sealing (McGovern and Bigelow, 1984; McGovern et al., 1996; Enghoff, 2003). This is illustrated in Fig. $6 \mathrm{~b}$ by the increasing relative proportion of marine mammal bones during the different phases of activity at a major farm of Brattahilð (Ø29a, Fig. 1a) (McGovern and Pálsdóttir, 2006) and by human isotopic data showing an increasing proportion of diet from marine source over the five centuries of the Greenland settlement (Arneborg et al., 1999).

The modern farming developments (section 2.2) demonstrate that cold years in such a marginal area as southern Greenland can have dramatic consequences for livestock. Soon after 1000 AD, a regime of more extreme climatic fluctuations was inferred from the outer Igaliku Fjord core with, since $\sim 1245$ AD, stronger advections of the cold East Greenland Current, more sea ice and lower summer temperatures (Jensen et al., 2004). A succession of harsh winters is also noted in the Dye- 3 winter $\delta^{18} \mathrm{O}$ record toward the end of the 12th century (Fig. 6b). It suggests that climate deterioration was likely the main driver of the evolution of the Norse subsistence pattern (Dugmore et al., 2009). This may have led to a decrease of sheep herds and related grazing pressure early before fully entering the 'Little Ice Age' indicated, in the early 15th century, by a negative shift in the Dye-3 winter $\delta^{18} \mathrm{O}$ record (Vinther et al., 2010; Fig. 6b) and by the culmination of a cooling in the Igaliku fjord at $\sim 1405 \mathrm{AD}$ (Lassen et al., 2004).

While Sandgren and Fredskild (1991) argue that the most severe erosion seems to have taken place at the end of the Norse era, our observations bring strong evidence of reduced agropastoral pressure a least one century before the abandonment, perhaps since $1230 \mathrm{AD}$ as indicated by the isotopic ratios of $\mathrm{N}$ and $\mathrm{C}$, in accordance to the climate deterioration and the changes in Norse diet. An early decrease in grazing intensity was also demonstrated close to a large Norse farm complex (Ø39, Fig. 1a) of the Eastern Settlement (Schofield and Edwards, 2011). The Igaliku record showed no continuous increase of soil erosion until the end of the Eastern Settlement, which contradicts the idea of catastrophic erosion due to overgrazing as the ultimate cause of the collapse of the Greenland Norse society. Moreover, the highest level of Norse soil erosion recorded at Igaliku, $8 \mathrm{~mm}$ century $^{-1}$ (2 sigma range of $6-12 \mathrm{~mm}$ century $^{-1}$ ) could even be considered as characteristic of conservation agriculture $(12.4 \pm 2.2 \mathrm{~mm}$ century $^{-1}$ ) (Montgomery, 2007).

\subsection{Incomplete recovery of the Igaliku lake system (ca 1450-1915 AD)}

Pollen assemblages indicate that the vegetation did not completely recover from Norse impacts (Gauthier et al., 2010). As for other studied sites (Fredskild, 1973, 1978) the most obvious footprint of Norse farming on vegetation at Igaliku is the persistence of Norse apophytes like Rumex acetosa and Ranunculus acris type which are widespread today around ruins of medieval farms (Fig. 6a). C:N ratio and $\delta^{13} \mathrm{C}$ to natural values and indicate a cessation of soil erosion associated with agriculture. Higher concentrations of titanium after the abandonment could be interpreted as a legacy of more than four centuries of Norse farming which could have altered the physicochemical properties of soils for a long time. However, a well documented change in climatic conditions occurred at the onset of the Little Ice Age. Initiated close to the end of the Norse Eastern Settlement ca. 1425 AD (Dugmore et al., 2007), this period was characterized by cold and dry air masses above the North Atlantic with increased wind speed and storm frequency which caused an enhanced deposition of eolian material (O'Brien et al., 1995; Christiansen, 1998; Willemse et al., 2003; Jackson et al., 2005). This is also apparent in the rise of sea salt spray in a peat bog deposit from Qinngua Kangilleq (Fig. 1a) located $50 \mathrm{~km}$ north from Igaliku (Schofield and Edwards, 2011). A shift to dry and windy conditions may have brought more aeolian dust to the Igaliku Lake basin and, with a possible persistent modification of soils properties due to Norse farming, it could contribute to higher Ti concentrations. 


\subsection{Impacts of modern agriculture (since $1915 A D$ )}

From the beginning of the 20th century to $\sim 1960$ ( $\pm 5 \mathrm{yr}$ ) no sedimentary parameter reveals any significant increase of erosion around the lake of Igaliku (Fig. 7a) suggesting that sheep grazing around the lake was minimal before that date. Since $\sim 1960$ the grazing pressure, once again revealed by a decline in woody taxa and a rise in coprophilous fungi (Fig. 6a) caused a progressive increase in soil erosion which started gently as indicated by subtle changes in all parameters except Ti. Soil erosion accelerated in 1969 $( \pm 4 \mathrm{yr})$, with a sharp increase in Ti and C:N ratio, to reach $\sim 11 \mathrm{~mm}$ century $^{-1}$ in 1988 ( $\pm 2.5 \mathrm{yr}$ ), slightly more than the medieval period (Fig. 7a). The year 1969 also marks the beginning of a steady increase in $\delta^{15} \mathrm{~N}$ for the remainder part of the profile. It may partly reflect an increase in primary productivity due to enhanced nutrient loading and also external contribution from enriched sources like animal dung (Teranes and Bernasconi, 2000).

Around 1988, major earthworks and digging of drainage ditches were carried out in both hayfields (Fig. 1b). At the same time, soil erosion increased dramatically, up to $21 \mathrm{~mm}$ century ${ }^{-1}$. After 1997 ( $\pm 2 \mathrm{yr}$ ), the erosion rate decreased continuously and may mark the stabilization of the material remobilized by the drainage works. This phase also corresponds to the four outliers in the organic matter geochemical composition (Fig. 5a and b). Despite the high level of soil erosion, the $\mathrm{C}: \mathrm{N}$ ratio continuously decreased due to the highest $\mathrm{N}$ concentrations of the core $(>0.6 \%)$. The $+1 \%$ offset in $\delta^{15} \mathrm{~N}$ could be attributed to the loss of ${ }^{14} \mathrm{~N}$ stimulated by greater primary production and deposition of nitrogen-rich organic matter (algal) due to the input of $\mathrm{N}$ fertilisers and barn effluents into the lake. This is supported by the sharp increase in the relative abundance of the mesotrophic diatom, Fragilaria tenera, from 10\% to 36\% after 1997 (Fig. 6a). However, early diagenesis effects on isotopical and elemental composition (Meyers and Ishiwatari, 1993; Lehmann et al., 2002), such as the preferential degradation of lake derived organic matter (Gälman et al., 2008), cannot be ruled out.
These two periods of soil erosion, 1960-1988 and 1988-2007, are consistent with the two modern agricultural phases of South Greenland (Fig. 7b) discussed in section 2.2. The former corresponds to the first phase of free-ranging sheep whereas the later is the expression of intensified practices and hay-field management that followed the agrarian reform of 1982. Consequently, the Igaliku lake system is undergoing the most important environmental changes of the last 2500 years, with soil erosion is 3-fold the Norse level. Even if soil loss inferior to $10 \mathrm{~mm}^{\text {century }}{ }^{-1}$ could be tolerable (Montgomery, 2007), the mean denudation rate refers to the whole catchment area of lake Igaliku ( $355 \mathrm{ha}$ ) and erosion on the plowed 30 ha hay-fields must be much higher.

\section{Synthesis and conclusion}

This study is the first quantification of soil erosion from a lake deposit of South Greenland. The results demonstrate that the Igaliku lake system is very sensitive to the human land use and permits a high resolution reconstruction of the history of agricultural impacts on the landscape. The estimation of sediment yield from an accurate core chronology as well as the use of geochemical parameters ( $\mathrm{C}: \mathrm{N}, \mathrm{Ti}, \delta^{15} \mathrm{~N}, \delta^{13} \mathrm{C}$ ) turned out to be two valuable and independent methods to investigate past soil erosion in subarctic lake systems.

Although other studies of lake sedimentary archives are needed before generalizing about the fate of the Greenland Norse settlements, our findings question the veracity of the catastrophic scenario of overgrazing and land degradation considered to have been one of the major factors responsible for their demise. The mutations of subsistence practices toward hunting and fishing have probably contributed to the reduction of grazing pressure and associated soil erosion which is recorded in the sediments of Lake Igaliku long before the end of the Eastern Settlement and therefore is unlikely to have been the prominent cause of its abandonment.

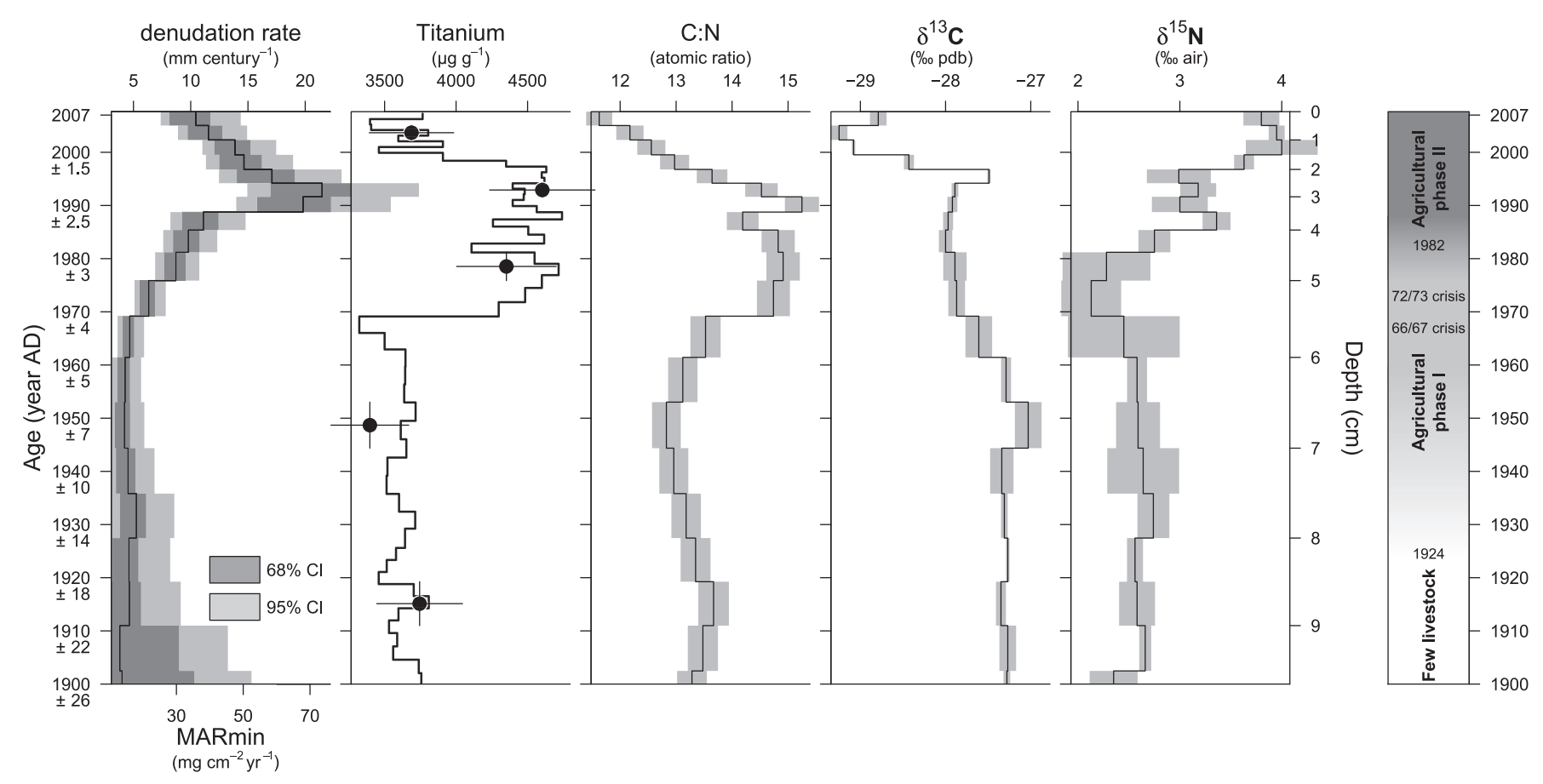

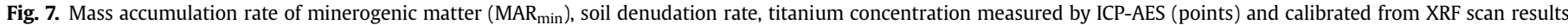

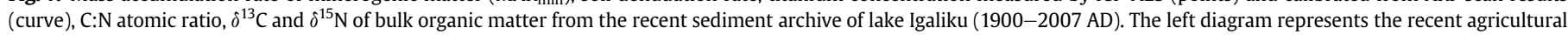
phases in South Greenland. 
Due to technological evolution, the medieval and modern farmers have followed diametrically opposed pathways in adaptation strategies to climate changes. Thus medieval and modern agricultures are not true analogues. In response to the succession of harsh winters, modern farmers have mechanically and chemically intensified their fodder production on the sparse arable lands to protect their livestock from other agricultural disasters. This caused unprecedented soil erosion that could have consequences for the future of Greenland agriculture which is expected to benefit from warming future climate.

\section{Acknowledgements}

This study is part of Charly Massa's PhD thesis (University of Franche-Comté). Coring campaign and analysis were supported by grants from the University of Franche-Comté, the University of Burgundy (France), the French Polar Institute (IPEV) and the ANR CEPS “Green Greenland” project. Hervé Grisey, Michel Campy and Boris Vannière provided invaluable assistance during the field work, which we gratefully acknowledge. Thanks also to Michel Magny and two anonymous reviewers, whose comments and suggestions improved the manuscript.

\section{References}

Abbott, M.B., Stafford Jr., T.W., 1996. Radiocarbon geochemistry of modern and ancient arctic lake systems, Baffin Island, Canada. Quaternary Research 45, $300-311$.

Andresen, C.S., Björck, S., Bennike, O., Bond, G., 2004. Holocene climate changes in southern Greenland: evidence from lake sediments. Journal of Quaternary Science 19, 783-795.

Appleby, P.G., Oldfield, F., 1978. The calculation of lead-210 dates assuming a constant rate of supply of unsupported ${ }^{210} \mathrm{~Pb}$ to the sediment. Catena $5,1-8$.

Arneborg, J., 2007. Saga trails. Brattahlid, Gardar, Hvalsey fjord's church and herjolfnesnes: four chieftain's farmsteads in the north settlements of Greenland. A visitor's guidebook, Copenhagen.

Arneborg, J., Heinemeier, J., Lynnerup, N., Nielsen, H.L., Rud, N., Sveinbjörnsdóttir, Á.E., 1999. Change of diet of the greenland vikings determined from stable carbon isotope analysis and $14 \mathrm{C}$ dating of their bones. Radiocarbon 41, 157-168.

Austrheim, G., Asheim, L.J., Bjarnason, G., Feilberg, J., Fosaa, A.M., Holand, Ø. Høegh, K., Jónsdóttir, I., Magnússon, B., Mortensen, L.E., Mysterud, A., Olsen, E., Skonhoft, A., Steinheim, G., Thórhallsdóttir, A.G., 2008. Sheep Grazing in the North-Atlantic Region - A Long Term Perspective on Management, Resource Economy and Ecology. NTNU Zoological Report 2008-3. Norwegian University of Science and Technology, Trondheim.

Barlow, L.K., Sadler, J.P., Ogilvie, A.E.J., Buckland, P.C., Amorosi, T. Ingimundarson, J.H., Skidmore, P., Dugmore, A.J., McGovern, T.H., 1997 Interdisciplinary investigations of the end of the Norse Western Settlement in Greenland. The Holocene 7, 489-499.

Battarbee, R., Bennion, H., 2010. Palaeolimnology and its developing role in assessing the history and extent of human impact on lake ecosystems. Journal of Paleolimnology, 1-6.

Blaauw, M., 2010. Methods and code for 'classical' age-modelling of radiocarbon sequences. Quaternary Geochronology 5, 512-518.

Bond, G., 1997. A pervasive millennial-scale cycle in North Atlantic Holocene and Glacial climates. Science 278, 1257.

Boyle, J., Plater, A., Mayers, C., Turner, S., Stroud, R., Weber, J., 2011. Land use, soil erosion, and sediment yield at Pinto Lake, California: comparison of a simplified USLE model with the lake sediment record. Journal of Paleolimnology 45, 199-212.

Buckland, P.C., Edwards, K.J., Panagiotakopulu, E., Schofield, J.E., 2009. Palaeoecological and historical evidence for manuring and irrigation at Gardar (Igaliku), Norse Eastern Settlement, Greenland. The Holocene 19, 105-116.

Cappelen, J., Jørgensen, B.V., Laursen, E.V., Stannius, L.S., Thomsen, R.S., 2001. The Observed Climate of Greenland, 1958-99 - With Climatological Standard Normals, 1961-90. DMI Technical Report No. 00-18. Danish Meteorological Institute, Copenhagen, p. 152.

Chiverrell, R., 2006. Past and future perspectives upon landscape instability in Cumbria, northwest England. Regional Environmental Change 6, 101-114.

Christensen-Bojsen, K.M., 1991. Land use and resource exploitation in the Norse western settlement in Greenland. Acta Borealia 8, 29-39.

Christiansen, H.H., 1998. 'Little Ice Age' nivation activity in northeast Greenland. The Holocene 8, 719-728.

Dansgaard, W., Johnsen, S.J., Reeh, N., Gundestrup, N., Clausen, H.B., Hammer, C.U., 1975. Climatic changes, Norsemen and modern man. Nature 255, 24-28.
Dearing, J., Jones, R., Shen, J., Yang, X., Boyle, J., Foster, G., Crook, D., Elvin, M., 2008. Using multiple archives to understand past and present climate-human-environment interactions: the lake Erhai catchment, Yunnan Province, China. Journal of Paleolimnology 40, 3-31.

Dearing, J.A., 1992. Sediment yields and sources in a welsh upland lake-catchment during the past 800 years. Earth Surface Processes and Landforms 17, 1-22.

Diamond, J., 2005. Collapse: How Societies Choose to Fail or Survive. Penguin/Allen Lane, London.

Dugmore, A., Borthwick, D., Church, M., Dawson, A., Edwards, K., Keller, C., Mayewski, P., McGovern, T., Mairs, K.A., Sveinbjarnardóttir, G., 2007. The role of climate in settlement and landscape change in the North Atlantic Islands: an assessment of cumulative deviations in high-resolution proxy climate records. Human Ecology 35, 169-178.

Dugmore, A.J., Church, M.J., Buckland, P.C., Edwards, K.J., Lawson, I., McGovern, T.H., Panagiotakopulu, E., Simpson, I.A., Skidmore, P., Sveinbjarnardóttir, G., 2005. The Norse landnám on the North Atlantic islands: an environmental impact assessment. Polar Record 41, 21-37.

Dugmore, A.J., Keller, C., McGovern, T.H., Casely, A.F., Smiarowski, K., 2009. Norse Greenland Settlement and Limits to Adaptation. In: Adger, W.N., Lorenzoni, I., O'Brien, K.L. (Eds.), Adapting to Climate Change: Thresholds, Values, Governance. Cambridge University Press, Cambridge.

Edwards, K.J., Schofield, J.E., Mauquoy, D., 2008. High resolution paleoenvironmental and chronological investigations of Norse landnam at Tasiusaq, Eastern Settlement, Greenland. Quaternary Research 69, 1-15.

Egede, K., 1982. Detailplan for fåreavlen i Sydgrønland. - Printed report. Fåreavlskonsulenttjenesten, Upernaviarssuk.

Enghoff, I.B., 2003. Hunting, Fishing and Animal Husbandry at the Farm Beneath the Sand, Western Greenland. An Archaeozoological Analysis of a Norse Farm in the Western Settlement. Meddelelser om Grønland, Man \& Society. 28 p.

Enters, D., Dorfler, W., Zolitschka, B., 2008. Historical soil erosion and land-use change during the last two millennia recorded in lake sediments of Frickenhauser See, northern Bavaria, central Germany. The Holocene 18, 243-254.

Feilberg, J., 1984. A phytogeographical study of South Greenland. Vascular plants. Meddelelser om Grønland, Bioscience 15, 1-69.

Fredskild, B., 1973. Studies in the vegetational history of Greenland. Meddelelser om Grønland 198, 1-245.

Fredskild, B., 1978. Palaeobotanical investigations of some peat deposits of Norse age at Qagssiarssuk, south Greenland. Meddelelser om Grønland 204, 1-41.

Fredskild, B., 1988. Agriculture in a Marginal area- South Greenland from the Norse Landnam (985 A.D.) to the present (1985 A.D.). In: Birks, H., Birks, H.J.B., Kaland, P.E., Dagfinn, M. (Eds.), Cultural Landscapes-Past, Present and Future. Cambridge University Press, Cambridge, pp. 381-393.

Fredskild, B., 1992. Erosion and vegetational changes in South Greenland caused by agriculture. Geografisk Tidsskrift 92, 14-21.

Gad, F., 1970. History of Greenland. In: Earliest Times to 1700, vol. 1. London and Hust Company, London.

Gälman, V., Rydberg, J., de-Luna, S.S., Bindler, R., Renberg, I., 2008. Carbon and nitrogen loss rates during aging of lake sediment: Changes over 27 years studied in varved lake sediment. Limnology Oceanography 53, 1076-1082.

Gauthier, E., Bichet, V., Massa, C., Petit, C., Vannière, B., Richard, H., 2010. Pollen and non-pollen palynomorph evidence of medieval farming activities in southwestern Greenland. Vegetation History and Archaeobotany 19, 427-438.

Greenland Agriculture Advisory Board, 2009. http://www.nunalerineq.gl/english/ landbrug/faare.htm (accessed 11.06.11).

Hansen, B.U., 1991. Monitoring natural vegetation in Southern Greenland using NOAA AVHRR and field measurements. Arctic 44, 94-101.

Hodell, D.A., Schelske, C.L., 1998. Production, sedimentation, and isotopic composition of organic matter in Lake Ontario. Limnology and Oceanography 43, 200-214.

Hua, Q., Barbetti, M., 2004. Review of tropospheric bomb C-14 data for carbon cycle modeling and age calibration purposes. Radiocarbon 46, 1273-1298.

Jackson, M.G., Oskarsson, N., Trønnes, R.G., McManus, J.F., Oppo, D.W., Grönvold, K., Hart, S.R., Sachs, J.P., 2005. Holocene loess deposition in Iceland: evidence for millennial-scale atmosphere-ocean coupling in the North Atlantic. Geology 33, 509-512.

Jacobsen, N.K., 1987. Studies on soils and potential for soil erosion in the sheep farming area of South Greenland. Arctic and Alpine Research 19, 498-507.

Jacobsen, N.K., Jakobsen, B.H., 1986. C14 datering af en fossil overfladehorisont ved Igaliku Kujalleq, Sydrønland, set i relation to nordboernes landnam. Geografisk Tidsskrift 86, 76-77.

Jakobsen, B.H., 1991. Soil resources and soil erosion in the Norse settlement area of Østerbygden in southern Greenland. Acta Borealia 8, 56-68.

Jensen, K.G., Kuijpers, A., Koc, N., Heinemeier, J., 2004. Diatom evidence of hydrographic changes and ice conditions in Igaliku Fjord, South Greenland, during the past 1500 years. The Holocene 14, 152-164.

Jinglu, W., Chengmin, H., Haiao, Z., Schleser, G., Battarbee, R., 2007. Sedimentary evidence for recent eutrophication in the northern basin of Lake Taihu, China: human impacts on a large shallow lake. Journal of Paleolimnology 38, 13-23.

Jones, G., 1986. The Norse Atlantic Saga: Being the Norse Voyages of Discovery and Settlement to Iceland, Greenland, and North America. Oxford University Press, New York.

Kaplan, M.R., Wolfe, A.P., Miller, G.H., 2002. Holocene environmental variability in Southern Greenland inferred from lake sediments. Quaternary Research 58, 149-159.

Kaufman, D.S., Schneider, D.P., McKay, N.P., Ammann, C.M., Bradley, R.S., Briffa, K.R. Miller, G.H., Otto-Bliesner, B.L., Overpeck, J.T., Vinther, B.M., Members, A.L.K.P., 2009. Recent warming reverses long-term arctic cooling. Science 325, 1236-1239. 
Kauppila, T., Salonen, V.P., 1997. The effect of Holocene treeline fluctuations on the sediment chemistry of Lake Kilpisjärvi, Finland. Journal of Paleolimnology 18, 145-163.

Kaushal, S., Binford, M.W., 1999. Relationship between C: N ratios of lake sediments, organic matter sources, and historical deforestation in Lake Pleasant, Massachusetts, USA. Journal of Paleolimnology 22, 439-442.

Klug, M., Schmidt, S., Bennike, O.L.E., Heiri, O., Melles, M., Wagner, B., 2009. Lake sediments from Store Koldewey, Northeast Greenland, as archive of Late Pleistocene and Holocene climatic and environmental changes. Boreas 38, 59-71.

Koinig, K.A., Shotyk, W., Lotter, A.F., Ohlendorf, C., Sturm, M., 2003. 9000 years of geochemical evolution of lithogenic major and trace elements in the sediment of an alpine lake - the role of climate, vegetation, and land-use history. Journal of Paleolimnology 30, 307-320.

Krogh, K.J., 1967. Viking Greenland: With a Supplement of Saga Text. The National Museum, Copenhagen.

Kuijpers, A., Mikkelsen, N., 2009. Geological records of changes in wind regime over south Greenland since the Medieval Warm Period: a tentative reconstruction. Polar Record 45, 1-8.

Kylander, M.E., Ampel, L., Wohlfarth, B., Veres, D., 2011. High-resolution X-ray fluorescence core scanning analysis of Les Echets (France) sedimentary sequence: new insights from chemical proxies. Journal of Quaternary Science $26,109-117$.

Lassen, S.J., Kuijpers, A., Kunzendorf, H., Hoffmann-Wieck, G., Mikkelsen, N., Konradi, P. 2004. Late-Holocene Atlantic bottom-water variability in Igaliku Fjord, South Greenland, reconstructed from foraminifera faunas. The Holocene $14,165-171$.

Lehmann, M.F., Bernasconi, S.M., Barbieri, A., McKenzie, J.A., 2002. Preservation of organic matter and alteration of its carbon and nitrogen isotope composition during simulated and in situ early sedimentary diagenesis. Geochimica et Cosmochimica Acta 66, 3573-3584.

Lu, Y., Meyers, P.A., Johengen, T.H., Eadie, B.J., Robbins, J.A., Han, H., 2010. $\delta 15 \mathrm{~N}$ values in Lake Erie sediments as indicators of nitrogen biogeochemical dynamics during cultural eutrophication. Chemical Geology 273, 1-7.

Mainland, I., 2006. Pastures lost? A dental microwear study of ovicaprine diet and management in Norse Greenland. Journal of Archaeological Science 33, $238-252$.

McGovern, T., 1991. Climate correlation and causation in Norse Greenland. Arctic Anthropology 28, 77-100.

McGovern, T., Amorosi, T., Perdikaris, S.P., Woollett, J.W., 1996. Zooarchaeology of Sandnes V51: economic change at a chieftain's farm in West Greenland. Arctic Anthropology 33, 94-122.

McGovern, T., Bigelow, G., Amorosi, T., Russell, D., 1988. Northern Islands, human error, and environmental degradation: a view of social and ecological change in the Medieval North Atlantic. Human Ecology 16, 225-270.

McGovern, T.H., Bigelow, G.F., 1984. The archaeozoology of the Norse Site Ø 17a Narssaq district, Southwest Greenland. Acta Borealia 1, 85-102.

McGovern, T.H., Pálsdóttir, A., 2006. Preliminary Report of a Medieval Norse Archaeofauna from Brattahlið North Farm (KNK 2629), Qassiarsuk, Greenland. NORSEC Zooarchaeology Laboratory Report 34, 1-22.

Meyers, P.A., Ishiwatari, R., 1993. Lacustrine organic geochemistry - an overview of indicators of organic matter sources and diagenesis in lake sediments. Organic Geochemistry 20, 867-900.

Migeon, S., Weber, O., Faugeres, J.C., Saint-Paul, J., 1999. SCOPIX: a new X-ray imaging system for core analysis. Geo-Marine Letters 18, 251-255.

Mikkelsen, N., Kuijpers, A., Lassen, S., Vedel, J., 2001. Marine and terrestrial investigations in the Norse Eastern Settlement, South Greenland. Geology of Greenland Survey Bulletin 189, 65-69.

Montgomery, D.R., 2007. Soil erosion and agricultural sustainability. Proceedings of the National Academy of Sciences of the United States of America 104, 13268-13272.

Nørlund, P., Roussell, A., 1929. Norse Ruins at Gardar. The episcopal seat of Mediaeval Greenland. Meddelelser om Grønland 76, 1-171.

O’Brien, S.R., Mayewski, P.A., Meeker, L.D., Meese, D.A., Twickler, M.S., Whitlow, S.I., 1995. Complexity of Holocene climate as reconstructed from a Greenland Ice Core. Science 270, 1962-1964.

Patterson, W.P., Dietrich, K.A., Holmden, C., Andrews, J.T., 2010. Two millennia of North Atlantic seasonality and implications for Norse colonies. Proceedings of the National Academy of Sciences of the United States of America 107, 5306-5310.
Peinerud, E.K., Ingri, J., Pontér, C., 2001. Non-detrital Si concentrations as an estimate of diatom concentrations in lake sediments and suspended material. Chemical Geology 177, 229-239.

Pennington, W., Tutin, T.G., Cambray, R.S., Fisher, E.M., 1973. Observations on lake sediments using fallout ${ }^{137} \mathrm{Cs}$ as a tracer. Nature $242,324-326$.

Perren, B., Massa, C., Bichet, V., Gauthier, É., Mathieu, O., Petit, C., Richard, H. A paleoecological perspective on 1450 years of human and climate impacts in South Greenland. The Holocene, in press.

Revel, M., Ducassou, E., Grousset, F.E., Bernasconi, S.M., Migeon, S., Revillon, S. Mascle, J., Murat, A., Zaragosi, S., Bosch, D., 2010. 100,000 Years of African monsoon variability recorded in sediments of the Nile margin. Quaternary Science Reviews 29, 1342-1362.

Roncaglia, L., Kuijpers, A., 2004. Palynofacies analysis and organic-walled dinoflagellate cysts in late-Holocene sediments from Igaliku Fjord, South Greenland. The Holocene 14, 172-184.

Rutherford, G.K., 1995. Soils of some norse settlements in Southwestern Greenland. Arctic 48, 324-328.

Sandgren, P., Fredskild, B., 1991. Magnetic measurements recording Late Holocene man-induced erosion in S. Greenland. Boreas 20, 315-331.

Sanmark, A., 2009. The case of the Greenlandic assembly sites. Journal of the North Atlantic 2, 178-192.

Santisteban, J.I., Mediavilla, R., López-Pamo, E., Dabrio, C.J., Zapata, M.B.R. García, M.J.G., Castaño, S., Martínez-Alfaro, P.E., 2004. Loss on ignition: a qualitative or quantitative method for organic matter and carbonate mineral content in sediments? Journal of Paleolimnology 32, 287-299.

Schelske, C.L., Hodell, D.A., 1995. Using carbon isotopes of bulk sedimentary organic matter to reconstruct the history of nutrient loading and eutrophication in Lake Erie. Limnology and Oceanography 40, 918-929.

Schofield, J., Edwards, K., 2011. Grazing impacts and woodland management in Eriksfjord: Betula, coprophilous fungi and the Norse settlement of Greenland. Vegetation History and Archaeobotany, 1-17.

Schofield, J.E., Edwards, K.J., Christensen, C., 2008. Environmental impacts around the time of Norse landnám in the Qorlortoq valley, Eastern Settlement, Greenland. Journal of Archaeological Science 35, 1643-1657.

Schofield, J.E., Edwards, K.J., Mighall, T.M., Martínez Cortizas, A., RodríguezRacedo, J., Cook, G., 2010. An integrated geochemical and palynological study of human impacts, soil erosion and storminess from southern Greenland since c. AD 1000. Palaeogeography, Palaeoclimatology, Palaeoecology 295, 19-30.

Stuiver, M., Grootes, P.M., Braziunas, T.F., 1995. The GISP2 delta $18{ }^{\circ}$ climate record of the past 16,500 years and the role of the sun, ocean, and volcanoes. Quaternary Research 44, 341-354.

Sugai, S.F., Alperin, M.J., Reeburgh, W.S., 1994. Episodic deposition and ${ }^{137} \mathrm{Cs}$ immobility in Skan Bay sediments: a ten-year ${ }^{210} \mathrm{~Pb}$ and ${ }^{137} \mathrm{Cs}$ time series. Marine Geology 116, 351-372.

Talbot, M.R., 2002. Nitrogen isotopes in palaeolimnology. In: Last, W.M., Smol, J.P (Eds.), Tracking Environmental Change Using Lake Sediments. Springer, Netherlands, pp. 401-439.

Teranes, J.L., Bernasconi, S.M., 2000. The record of nitrate utilization and productivity limitation provided by $\delta^{15} \mathrm{~N}$ values in lake organic matter-a study of sediment trap and core sediments from Baldeggersee, Switzerland. Limnology and Oceanography $45,801-813$.

Tjallingii, R., Röhl, U., Kölling, M., Bickert, T., 2007. Influence of the water content on $\mathrm{X}$-ray fluorescence core-scanning measurements in soft marine sediments. Geochemistry Geophysics Geosystems 8, Q02004.

Upton, B.G.J., Emeleus, C.H., Heaman, L.M., Goodenough, K.M., Finch, A.A., 2003. Magmatism of the mid-Proterozoic Gardar Province, South Greenland: chronology, petrogenesis and geological setting. Lithos 68, 43-65.

Vinther, B.M., Jones, P.D., Briffa, K.R., Clausen, H.B., Andersen, K.K., Dahl-Jensen, D. Johnsen, S.J., 2010. Climatic signals in multiple highly resolved stable isotope records from Greenland. Quaternary Science Reviews 29, 522-538.

Wagner, B., Bennike, O., Bos, J., Cremer, H., Lotter, A., Melles, M., 2008 A multidisciplinary study of Holocene sediment records from Hjort Sø on Store Koldewey, Northeast Greenland. Journal of Paleolimnology 39, 381-398.

Willemse, N.W., 2002. Holocene Sedimentation History of the Shallow Kangerlussuaq Lakes, West Greenland. Meddelelser om Grønland, Geoscience 41, 1-48.

Willemse, N.W., Koster, E.A., Hoogakker, B., van Tatenhove, F.G.M., 2003. A continuous record of Holocene eolian activity in West Greenland. Quaternary Research 59, 322-334 